\title{
Booster Vaksinasi Hepatitis B Terhadap Anak yang Non Responder
}

\author{
Kusnandi Rusmil, ${ }^{*}$ Eddy Fadlyana, * Novillia S Bachtiar ** \\ ${ }^{*}$ Bag.Ilmu Kesehatan Anak RS.Hasan Sadikin/FK.UNPAD Bandung \\ **PT.Bio Farma
}

\begin{abstract}
Latar belakang. Berbagai penelitian terhadap respons imun setelah imunisasi hepatitis B dengan menggunakan vaksin monovalen dari plasma maupun yang berasal dari teknik DNA rekombinan menunjukkan antara 5\%15\% tidak memberikan respons (non-responder) atau kurang memberikan respons (hypo-responder) Center of Disease Control merekomendasikan terhadap anak yang tidak mempunyai tingkat proteksi antibodi (anti-Hbs) setelah mendapat imunisasi dasar, perlu diberikan 3 kali suntikan rangkaian ke-2. Setelah rangkaian ke-2 imunisasi Hepatitis B tersebut maka 30\%-50\% diantaranya akan mempunyai kadar yang protektif.

Tujuan. Penelitian bertujuan mengeksplorasi lebih mendalam mengenai manfaat pemberian vaksinasi rangkaian kedua pada anak hipo dan non responder sebagai salah satu data yang dapat dipergunakan strategi menghadapi masalah hepatitis B di Indonesia.

Metode. Penelitian dilakukan terhadap 144 anak yang telah melaksanakan imunisasi dasar hepatitis B secara lengkap (3 kali) yang merupakan bagian uji klinis vaksin pentavalen (DPT/hepatitis B/Hib). Enam bulan setelah mengetahui kadar anti-Hbs hasil uji klinik pentavalen dilakukan pemberian imunisasi rangkaian ke-2 pada anak-anak hipo/non-responder.

Hasil. Sebelas anak mempunyai kadar anti-Hbs $<10 \mathrm{mIU} / \mathrm{ml}$ (non/hypo responder terhadap vaksinasi Hepatitis B). Terhadap kesebelas anak tersebut dilakukan pemeriksaan kadar anti-Hbs setelah 6 bulan pemberian imunisasi hepatitis B-3, didapatkan 3 anak $(27,2 \%)$ mengalami peningkatan sehingga mempunyai kadar anti-Hbs $>10 \mathrm{mIU} / \mathrm{ml}, 8$ orang anak (72,2\%) mempunyai kadar $<10 \mathrm{mIU} / \mathrm{ml}$. Pada 8 anak tersebut dilakukan imunisasi rangkaian ke-2 hepatitis B sebanyak 3 kali. Setelah mendapat rangkaian ke-2 imunisasi Hepatitis B, kedelapan subjek (100\%) mencapai kadar protektif (>10 mIU/ml).

Kesimpulan. Pemberian 3 dosis standar hepatitis B dapat digunakan untuk memberikan kekebalan pada anak sehat dengan hypo/non responder. (Sari Pediatri 2010;12(2):88-91).
\end{abstract}

Kata kunci: vaksinasi hepatitis B, hypo/non-responder, anak

Alamat korespondensi:

DR. Kusnandi Rusmil, dr., Sp.A(K). Bagian/UPF Ilmu Kesehatan Anak FKUP/RSUP dr. Hasan Sadikin Jl. Pasteur No. 38 Telp./Fax. 2034426203595 Bandung 40161
$\mathrm{H}$ epatitis B merupakan infeksi virus hepatitis yang sering terjadi dan melibatkan jutaan orang di dunia. Kurang lebih tiga perempat penduduk dunia hidup di wilayah dengan tingkat penularan yang tinggi. Infeksi Hepatitis B merupakan predisposisi terjadinya sirosis 
hati dan karsinoma hati. ${ }^{1,2}$ Untuk mendapatkan respon imun terhadap vaksin hepatitis B yang optimal, dosis vaksin yang dipergunakan adalah 10 ugr perdosis dalam 0,5 cc/intramuskular, diberikan pada usia 0-1 bulan. Dosis ke-2 diberikan satu bulan berikutnya dan dosis ke-3 diberikan 3-6 bulan setelah suntikan pertama. ${ }^{3}$ Di lapangan/Puskesmas dan Posyandu, agar lebih memudahkan pelaksanaan imunisasi hepatitis B diberikan dengan interval minimal satu bulan setelah dosis yang ke-2. Seseorang dianggap kebal terhadap infeksi virus hepatitis B bila mempunyai kadar anti$\mathrm{Hbs}>10 \mathrm{mIU} / \mathrm{ml}$ (kadar proteksi). ${ }^{4}$

Dari berbagai penelitian terhadap respon imun setelah imunisasi hepatitis B dengan menggunakan vaksin monovalen yang berasal dari plasma maupun yang berasal dari teknik DNA rekombinan menunjukkan antara 5\%-15\% tidak memberikan respon (non-responder) atau kurang memberikan respon (bypo-responder) artinya antibodi yang terbentuk di bawah ambang protektif atau tidak terbentuk sama sekali. ${ }^{5-8}$ Hepatitis B Foundation mendefinisikan non responder sebagai ketidakmampuan membentuk anti-Hbs yang protektif setelah mendapatkan dua seri lengkap imunisasi hepatitis B, setelah infeksi hepatitis B baik akut maupun kronis sudah disingkirkan. ${ }^{9}$ Istilah non-responder menjadi non-responder primer sesuai dengan definisi yang diajukan oleh Hepatitis $B$ Foundation dan hypo-responder yang dapat memberikan respons setelah seri imunisasi yang kedua. Diperkirakan sekitar 5\%-15\% orang merupakan non-responder. Center for American Disease Control merekomendasikan terhadap anak yang tidak mempunyai tingkat proteksi antibodi (anti-Hbs) setelah mendapat imunisasi dasar, maka diberikan tiga kali suntikan rangkaian ke-2. Setelah rangkaian ke-2 imunisasi Hepatitis B tersebut maka 30\%-50\% diantaranya mencapai kadar yang protektif. ${ }^{10}$

Tujuan penelitian untuk mengetahui proporsi hypolnon-responder setelah pemberian imunisasi dasar hepatitis $\mathrm{B}(3 \mathrm{x})$ pada bayi sehat dan mengetahui respon antibodi terhadap hepatitis B pada anak hypo/nonresponder terhadap imunisasi dasar hepatitis B setelah mendapat rangkaian imunisasi hepatitis B ke-2.

\section{Metode}

Penelitian merupakan lanjutan dari uji klinik fase II vaksin pentavalen (DTP/HepB/Hib) di Bagian
Ilmu Kesehatan Anak FKUP/RS dr. Hasan Sadikin Bandung, pada bulan Desember 2003 - Desember 2004. Kriteria inklusi ádalah semua peserta penelitian uji klinis pentavalen fase II, sehat secara klinis, dan orangtua menyetujui anaknya ikut serta dalam penelitian. Kriteria eksklusi adalah anak menderita infeksi virus hepatitis $B$, telah mendapat imunisasi tambahan di tempat pelayanan kesehatan lainnya, dan anak pernah atau sedang mendapat pengobatan yang dapat mengubah sistem kekebalan tubuh dalam dua minggu terakhir.

Anak dengan hasil pemeriksaan anti-Hbs $<10$ $\mathrm{mIU} / \mathrm{ml}$, maka dikategorikan kelompok non-responder atau hypo-responder, dan apabila memenuhi kriteria inklusi dimasukkan sebagai subjek penelitian. Nonresponders apabila anak tidak mempunyai tingkat proteksi (anti-Hbs), setelah mendapat serangkaian imunisasi dasar. Hypo-responders apabila mempunyai kadar antibodi di bawah nilai proteksi ( $\mathrm{Hbs}<10 \mathrm{mIU} /$ $\mathrm{ml}$ ), setelah mendapat serangkaian imunisasi dasar hepatitis B.

\section{Hasil}

Dalam penelitian uji klinis pentavalen 144 anak mengikuti secara lengkap uji klinis imunisasi hepatitis B (3 X imunisasi hepatitis B). Di antara 144 anak tersebut, 11 anak mempunyai kadar anti-Hbs $<10$ $\mathrm{mIU} / \mathrm{ml}$ (non/hypo responder terhadap imunisasi Hepatitis B). Terhadap kesebelas anak tersebut dilakukan pemeriksaan kadar anti-Hbs enam bulan setelah pemberian imunisasi hepatitis B 3, 3 anak $(27,7 \%)$ mengalami peningkatan sehingga mempunyai kadar anti-Hbs $>10 \mathrm{mIU} / \mathrm{ml}$ walaupun tidak mendapat imunisasi. Pada 8 orang anak (72.2\%), kadar antiHbs masih $<10 \mathrm{mIU} / \mathrm{ml}$. Pada mereka yang masih mempunyai kadar $<10 \mathrm{mlU} / \mathrm{ml}$ dilakukan imunisasi hepatitis B rangkaian ke-2 (booster) sebanyak tiga kali. Setelah mendapat booster, kedelapannya (100\%) mempunyai kadar anti-Hbs di atas nilai protektif (> $10 \mathrm{mIU} / \mathrm{ml})$.

\section{Pembahasan}

Hasil pemberian imunisasi pentavalen (DPT + Hep $\mathrm{B}+\mathrm{Hib})$ terhadap bayi sehat dengan jadwal 6, 10, dan 14 minggu (dipublikasikan di jurnal lain), 
Tabel 1. Kadar anti-Hbs pre imunisasi dasar, pre dan pasca rangkaian ke-2 imunisasi Hepatitis B, pada subjek yang mempunyai kadar anti-Hbs $<10 \mathrm{mIU} / \mathrm{ml}$.

\begin{tabular}{ccccc}
\hline No inklusi & $\begin{array}{c}\text { Titer antibodi pre } \\
\text { imunisasi dasar } \\
\mathrm{mIU} / \mathrm{ml}\end{array}$ & $\begin{array}{c}\text { Titer antibodi } \\
\text { imunisasi dasar } \\
\mathrm{mIU} / \mathrm{ml}\end{array}$ & $\begin{array}{c}\text { Titer antibodi } \\
\text { 6 bulan pasca } \\
\text { imunisasi dasar } \\
\mathrm{mIU} / \mathrm{ml}\end{array}$ & $\begin{array}{c}\text { Titer antibodi pasca } \\
\text { imunisasi rangkaian } \\
\text { ke-2 } \\
\mathrm{mIU} / \mathrm{ml}\end{array}$ \\
\hline 6 & 3.4 & 0.0 & 0.0 & 974 \\
23 & 0.0 & 2.7 & 0.0 & 5180 \\
37 & 0.0 & 8.5 & 38.8 & 2802 \\
40 & 20.4 & 6.1 & 14.5 & 3350 \\
41 & 0.0 & 0.0 & 13.9 & 482.2 \\
44 & 0.0 & 0.0 & 0.0 & 12.8 \\
71 & 0.0 & 0.0 & 0.0 & 745.7 \\
78 & 10.8 & 0.0 & 0.0 & 416.4 \\
86 & 0.0 & 2.5 & 1.3 & 1558 \\
98 & 0.0 & 0.0 & 1.1 & 341.2 \\
134 & 0.0 & 9.4 & 0.0 & 2675 \\
\hline
\end{tabular}

menunjukkan delapan bayi diantaranya tidak/kurang menghasilkan antibodi terhadap hepatitis B (5,5\%). Hasil tersebut tidak berbeda dengan hasil penelitian di Amerika Serikat, pada umumnya anak yang sudah mendapat imunisasi dasar hepatitis B akan memberikan respon yang baik dan sekitar 5\%-10\% tidak memberikan respon.6-8,11

Setelah pemberian imunisasi hepatitis B rangkaian ke-2 dengan jadwal tiga kali pemberian imunisasi hepatitis B dengan interval satu bulan, menunjukkan semua bayi ( 8 bayi) mempunyai titer anti-Hbs $>10$ $\mathrm{mIU} / \mathrm{mL}$ (100\%). Temuan tersebut berbeda dengan penelitian di Amerika Serikat yang menunjukkan 2,5\% tetap tidak memberikan respons setelah rangkaian imunisasi hepatitis B yang ke-2. Maka pada saat ini dikembangkan vaksin hepatitis $B$ generasi baru untuk lebih meningkatkan seroproteksi untuk mengurangi jumlah non-reponders. ${ }^{12}$

Pada anak yang tidak memberikan respons setelah imunisasi hepatitis B rangkaian pertama, pada umumnya akan memberikan respons yang baik apabila diberikan imunisasi hepatitis $\mathrm{B}$ rangkaian ke-2. Berdasarkan laporan dari CDC Amerika Serikat, 15\%-25\% akan memberikan respons setelah satu dosis tambahan dan 30\%-50\% setelah tiga dosis tambahan. ${ }^{10}$

Salah satu sebab tidak timbulnya respons terhadap imunisasi, kemungkinan anak sedang menderita hepatitis B. Maka pada penelitian kami telah dilakukan skrining awal dengan pemeriksaan HbsAg. Beberapa faktor lainnya yang ikut berperan dalam peningkatan antibodi adalah tempat dan cara penyuntikan yang tidak sesuai, area deltoid lebih baik dibandingkan area gluteus karena lemak akan menghambat aktivasi antigen presenting cells, sehingga menyebabkan presentasi antigen sel $\mathrm{T}$ dan B terhambat. ${ }^{13}$ Jenis kelamin, umur tua, kegemukan, kebiasaan merokok atau sedang menderita gangguan kekebalan pada tubuhnya juga dapat menghambat pembentukan antibodi.

Kesimpulan penelitian ini adalah setelah diberikan tiga kali suntikan imunisasi hepatitis B rangkaian ke dua pada anak yang hypo/non-responder terhadap imunisasi dasar hepatitis B didapatkan seluruh anak mencapai kadar anti-Hbs yang protektif.

\section{Ucapan terimakasih}

Penulis mengucapkan terima kasih kepada PT Bio Farma yang telah membantu penelitian ini, khususnya Drs. Mahendra Suhardono, Kepala bagian Ilmu Kesehatan Anak Universitas Padjadjaran, Prof. Suganda Tanuwidjaya,dr.,Sp.A(K) atas asupannya, Pimpinan Puskesmas Garuda Dr. Dina Puger, Pimpinan Puskesmas Puter dr. Awapurwanti yang telah memfasilitasi dengan sebaik-baiknya sebagai tempat penelitian dilaksanakan.

\section{Daftar pustaka}

1. World Health Organization. Hepatitis B. Department of Communicable Disease Surveillance and Response. 
Geneva, 2010.

2. McMahon, BJ. Epidemiology and natural history of hepatitis B. Semin Liver Dis 2005; 25 Suppl 1:3.

3. Mast E, Goldstein S, Ward JL. Hepatitis B vaccine. Dalam: Plotkin SA, Orenstein WA, penyunting. Vaccines. Edisi ke-5. Philadelphia: W.B. Saunders; 2004. h. 299-337.

4. Subdit imunisasi, Ditjen PPM \& PL Kementrian Kesehatan 1999.

5. Boerhan H, Poernamawati. Hepatitis B. Dalam: Ranuh IGN, Suyitno H, Hadinegoro SR, Kartasasmita CB, penyunting.Pedoman imunisasi di Indonesia. Edisi ke-3. IDAI; 2008.h.135-42.

6. Kubba AK, Taylor P, Graneek B, Strobel S. Nonresponders to hepatitis $\mathrm{B}$ vaccination: A review. Commun Dis Public Health 2003;6:106-12.

7. Poland, GA. Hepatitis B immunization in health care workers. Dealing with vaccine nonresponse. Am J Prev Med 1998; 15:73.
8. Wood RC, MacDonald KL, White KE, Hedberg CW, Hanson M, Osterholm MT. Risk factors for lack of detectable antibody response following hepatitis $\mathrm{B}$ vaccination of Minnesota health care workers. JAMA 1993;270:2935-9.

9. Hepatitis B Foundation. Hepatitis B vaccine. Didapat dari: http:www.hepp.org. Diakses tanggal 1 Agustus 2010.

10. Centers for Deasease Control and Prevention. Recommended Immunization Schedules for Persons Aged 0 through 18 years - United States, MMWR Recomm Rep 2010;58.

11. Eddleston A. Modem vaccines: hepatitis. Lancet 1990;335:1142-4.

12. Rottinghaus ST, Poland GA, Jacobson RM, Barr LJ, Roy MJ. Hepatitis B DNA vaccine induces protective antibody responses in human non-responders to conventional Vaccine. 2003;21:4604-08.

13. Zuckerman JN, Cockcroft A, Zuckerman AJ. Site of injection for vaccination. BMJ 1992;305:1158. 